\title{
PENGARUH SALES PROMOTION TERHADAP PERILAKU KONSUMEN DALAM MEMBELI KENDERAAN BERMOTOR RODA DUA \\ (Studi Kasus CV. Indah Sakti Rantauprapat)
}

Desmawaty Hasibuan

Dosen Tetap Sekolah Tinggi Ilmu Ekonomi (STIE) Labuhanbatu

\begin{abstract}
ABSTRAK
Penelitian ini bertujuan untuk mengetahui pengaruh sales promotion terhadap perilaku konsumen pada $C V$. Indah Sakti Rantauprapat tentang perilaku konsumen membeli sepeda motor Honda. Populasi dalam penelitian ini adalah konsumen CV. Indah Sakti Rantauprapat untuk periode semester I tahun 2014 yang berjumlah 123 orang. Selanjutnya dengan menggunakan rumus slovin tertentu ditetapkanlah jumlah sampel sehingga diperoleh sampel sebanyak 55 responden. Sumber data menggunakan data primer yakni kuesioner. Analisis data menggunakan aplikasi SPSS for Windows versi 18.00 yakni analisis regresi sederhana. Hasil penelitian menunjukkan bahwa variabel sales promotion berpengaruh signifikan terhadap perilaku konsumen pada $C V$. Indah Sakti Rantauprapat.
\end{abstract}

Kata Kunci : Sales Promotion dan Perilaku Konsumen

\section{PENDAHULUAN}

Perilaku konsumen pada dasarnya merupakan proses memilih, membeli dan menggunakan produk untuk memenuhi kebutuhan. Seiring dengan perkembangan informasi yang didukung teknologi dan meningkatnya kebutuhan akan alat transportasi merupakan angin segar bagi perusahaan otomotif khususnya sepeda motor, dimana sangat dibutuhkan oleh banyak orang selain ekonomis, harganya terjangkau dan mudah perawatannya serta banyak sekali bermunculan merek sepeda motor dengan berbagai model dan inovasi.

Salah satu perusahaan agen resmi distributor merek sepeda motor Honda di Indonesia yakni CV. Indah Sakti Rantauprapat hal ini merupakan suatu peluang untuk menguasai pangsa pasar. Guna menghadapi persaingan tersebut sepeda motor merek Honda selalu menciptakan penemuan-penemuan baru yang mana disesuaikan dengan perkembangan jaman dan keinginan dari masyarakat agar produknya tetap laku.

Untuk mencapai kesuksesan dalam pemasaran perlu didukung pemahaman yang baik mengenai perilaku konsumen. Dengan memahami perilaku konsumen CV. Indah Sakti Rantauprapat dapat merancang apa saja yang konsumen inginkan. Perilaku konsumen adalah perilaku yang diperlihatkan konsumen dalam mencari, membeli, menggunakan, mengevaluasi, dan menghabiskan produk dan jasa yang mereka harapkan akan memuaskan kebutuhan mereka. 
Perilaku konsumen merupakan proses tindakan-tindakan yang secara langsung terlibat dalam usaha untuk memperoleh, menggunakan, dan menentukan produk dan jasa, termasuk proses pengambilan keputusan yang mendahului dan mengikuti tindakantindakan tersebut, sehingga untuk menarik minat beli konsumen akan suatu barang, maka CV. Indah Sakti Rantauprapat harus mengetahui perilaku konsumen yang menjadi sasaran. Bila hal tersebut dapat dilakukan, maka perusahaan yang bersangkutan akan dapat meraih keuntunganyang jauh lebih besar dari pada pesaingnya, karena dengan dipahaminya perilakukonsumen, CV. Indah Sakti Rantauprapat dapat memberikan kepuasan secara lebih baik kepada konsumen.

Pemasaran memiliki peranan penting dalam sebuah perusahaan, karena pemasaran merupakan kegiatan utama perusahaan untuk menyalurkan produk atau jasa yang dihasilkan sampai ketangan konsumen, oleh karena itu CV. Indah Sakti Rantauprapat dituntut untuk membuat strategi yang tepat dalam memasarkan produknya, salah satu cara yang dapat dilakukan yaitu dengan melakukan bauran pemasaran. Produk, harga, distribusi, dan promosi merupakan variabel-variabel dari bauran pemasaran yang dapat mempengaruhi dan mendorong konsumen untuk menggunakan produk atau jasa yang ditawarkan perusahaan. Akan tetapi dengan semakin ketatnya persaingan maka CV. Indah Sakti Rantauprapat memfokuskan usaha yang dapat dilakukan untuk merebut simpatikonsumen yaitu dengan melakukan promosi.Promosi CV. Indah Sakti Rantauprapat lebih menekankan kepada promosi penjualan (sales promotion).

Sales promotion merupakan suatu kegiatan perusahaan untuk menjajakan produk yang dipasarkan sedemikian rupa sehingga konsumen akan mudah untuk melihatnya dan bahkan dengan cara penempatan dan pengaturan. Dengan tersedianya promosi yang beraneka ragam bukan berarti terbuka kesempatan bagi CV. Indah Sakti Rantauprapat untuk begitu saja memilih tanpa pertimbangan yang matang. Semakin beraneka ragam media promosi yang dipakai justru semakin banyak faktor yang perlu dijadikan bahan pertimbanganperusahaan sebelum melakukan kegiatan promosi.

Berdasarkan semakin tingginya kebutuhan masyarakat terhadap alat transportasi pribadi berupa sepeda motor dan meningkatnya persaingan untuk merebut konsumen serta pasar selalu dinamis dalam hal persaingan dan semakin menuntut pihak pemasar untuk melakukan antisipasi pemasaran produknya, maka penting untuk meneliti tentang masalah pengaruh sales promotion terhadap perilaku konsumen pada CV. Indah Sakti Rantauprapat.

\section{Tujuan Penelitian}

Penelitian ini bertujuan untuk mengetahui pengaruh sales promotion terhadap perilaku konsumen pada CV. Indah Sakti Rantauprapat.

\section{Landasan Teori Pengertian Pemasaran}

Pemasaran adalah salah satu kegiatan-kegiatan pokok dalam suatuperusahaan untuk mempertahankan hidup dan untuk mendapatkanlaba/keuntungan. Kegiatan pemasaran dalamperusahaan harus dapatmemberikan kepuasan kepada konsumen agar perusahaan tetap biasberkembang, atau konsumen mempunyai pandangan baik terhadapperusahaan tersebut. Pengertian pemasaran menurut Kotler danArmstrong (2008:6)," merupakan proses di mana perusahaan menciptakannilai bagi pelanggan dan 
membangun hubungan yang kuat denganpelanggan dengan tujuan untuk menangkap nilai dari pelanggan sebagaiimbalannya".

MenurutPeter Drucker dalam Kotler (2008:6), "Tujuanpemasaran adalah membuat penjualan tidak diperlakukan lagi". Penjualandan iklan hanyalah bagian dari bauran pemasaranyang lebih besarseperangkat sarana pemasaran yang bekerja sama untuk memuaskankebutuhan pelanggan dan menciptakan hubungan dengan pelanggan.Perusahaan yang sudah mulai mengenal dan memahami bahwapemasaran merupakan faktor penting dalam mencapai kesuksesanperusahaan konsep pemasaran bertujuan memberikan kepuasan terhadapkeinginan dan kebutuhan konsumen. Menurut Kotler(1994:34),"Konseppemasaran adalah suatu orientasiterhadap kebutuhan dan keinginanpelanggan, didukung olehsuatu pemasaran secara terpadu yang ditujukanuntuk membangkitkan kepuasan pelanggan sebagai kunci untukmemenuhi tujuan-tujuan organisasi".

MenurutTjiptono(2008:22),Konsep pemasaran (marketing concept)berpandangan bahwa kunci untuk mewujudkan tujuan organisasiterletakpada kemampuan organisasi dalam menciptakan, memberikan danmengkomunikasikan nilai pelanggan(costumer value) kepada pasarsasarannya secara lebih efektif dibandingkan pada pesaingTujuan akhir pemasaran adalah membantu organisasimencapaitujuannya. Tujuan utama dalam perusahaan adalah mencari laba.Sedangkan tujuan lainnya adalah mendapatkan dana yang memadaiuntuk melakukan aktivitas-aktivitas sosial dan pelayanan publik.

\section{Sales Promotion}

Sales promotionatau promosi penjualan dari alat insentif yang beraneka ragam, kebanyakan untuk meningkatkan penjualan baik jangka pendek maupun jangka panjang, dirancang ntuk merangsang pembelian produk tertentu agar lebih cepat dan atau lebih kuat oleh konsumen atau pedagang.Pengertian promosi penjualan (sales promotion) menurutWilliam F. Sehoell yang dikutip oleh Buchari Alma (2007:188) menyatakan bahwa :"Sales promotion is any activity that offers an incentiveor a limited period to induce a desired response fromtarget customers, company sales people or intermediaries."Sedangkan menurut Kotlerdan Amstrong yang dikutip kembali oleh Buchari Alma (2007:188) menyatakan bahwa :"Sales promotion consists of short term incentiveto encourage purchase or sales of a product or service."Dari kedua pengertian di atas maka dapat disimpulkan bahwa promosi penjualan(sales promotion) adalahkeinginan menawarkan insentif dalam periode tertentu untuk mendorong keinginan calon konsumen, para penjual atau perantara.Kegiatan advertising biasanya disertai oleh kegiatan alat promosi lain, yaitu sales promotion dan public relation. Tugas advertising ialah memberi ajakan kepada calon konsumen untuk mengenal dan membeli produk, sedangkan sales promotion mengajak mereka agar membelisekarang.Promosi penjualan(sales promotion) terdiri dari serangkaian teknik yang digunakan untuk mencapai sasaran-sasaran pemasaran dengan menggunakan dengan menggunakan biaya yang efisien dengan memberikan nilai tambah pada produk atau jasa kepada perantara maupun pemakai langsung, biasanya tidak dibatasi pada jangka waktu tertentu. 


\section{Perilaku Konsumen}

Menurut Engel et al dalamSopiahdan Sangadji(2013:7), perilaku konsumen adalah tindakan yang langsung terlibat dalam pemerolehan, pengonsumsian, dan penghabisan produk atau jasa, termasuk proses yang mendahului dan menyusul tindakan tersebut.Menurut Griffin dalamSopiah dan Sangadji (2013:8), perilaku konsumen adalah semua kegiatan, tindakan, serta proses psikologi yang mendorong tindakan tersebut pada saat sebelum membeli, ketika membeli, menggunakan, menghabiskan produk dan jasa setelah melakukan hal-hal diatas atau kegiatan mengevaluasi.Menurut Hasan (2013:161), perilaku konsumen adalah studi proses yang terlibat ketika individu atau kelompok memilih,membeli, menggunakan, atau mengatur produk, jasa, idea atau pengalaman untuk memuaskan kebutuhan dan keinginankonsumen.Menurut Schiffman dan Kanuk dalamSumarwandkk(2012:186) mendefinisikan perilaku konsumen sebagai tindakan yang langsung terlibat dalam mendapatkan, mengonsumsi dan menghabiskan produk atau jasa, termasuk proses keputusan yang mendahului dan mengikuti tindakan ini. Menurut Kotler dan Keller (2009:166) Perilaku konsumen adalah studi tentang bagaimana individu, kelompok, dan organisasi memilih, membeli, menggunakan, dan bagaimana barang, jasa, ide, atau pengalaman untuk memuaskan kebutuhan dan keinginan mereka.Menurut Sunyoto (2012:251) Perilaku konsumen (consumer behavior) dapat didefinisikan kegiatan-kegiatan individu yang secara langsung terlibat dalam mendapatkan dan mempergunakan barang-barang atau jasa termasuk didalamnya proses pengambilan keputusan pada persiapan dalam penentuan kegiatan-kegiatan tersebut. Perilaku konsumen memiliki kepentingan khusus bagi orang yang dengan berbagai alasan berhasrat untuk mempengaruhi atau mengubah perilaku tersebut,termasuk orang yang kepentingan utamanya adalah pemasaran. Tidak mengherankan jika studi tentang perilaku konsumen ini memiliki akar utama dalam bidang ekonomi terlebih lagi dalam pemasaran.

\section{Metode Penelitian}

Metode penelitian yang digunakan adalah analisa kuantitatif, dengan format penelitian eksplanasi yaitu penelitian yang ingin melihat hubungan atau korelasi di antara dua variabel yaitu variabel bebas dan variabel terikat (Bungin, 2001:51). Sebagai variabel bebas adalah sales promotion dan variabel terikat adalah jumlah penjualan kenderaan bermotor roda dua yang kemudian diuji melalui statistik. Populasi dalam penelitian ini adalah konsumen CV. Indah Sakti Rantauprapatuntuk periode semester I tahun 2014 yang berjumlah 123 orang. Selanjutnya dengan menggunakan rumus slovin tertentu ditetapkanlah jumlah sampel.

$$
n=\frac{N}{1+N \cdot e^{2}} \frac{123}{1+123 \cdot(0,1)^{2}}=55,15
$$

Di mana: $\mathrm{n}=$ jumlah sampel $\mathrm{N}=$ jumlah populasi $\mathrm{d}=$ presisi, ditetapkan $10 \%$ dengan derajat kepercayaan $90 \%$.

Dengan demikian jumlah responden yang dijadikan obyek penelitian ini digenapkan menjadi 55 orang. Namun populasi dari penelitian ini mempunyai tingkatan ekonomi yang berbeda (heterogen). 


\section{Analisis Data}

Analisis kuantitatif adalah analisis yang digunakan untuk menyajikan data dan dalam bentuk angka. Data pada penelitian ini adalah data ordinal. Penulis menganalisis data sebagai berikut :

\section{Metode Regresi Linear Sederhana}

Metode Regresi Sederhana digunakan untuk perumusan masalah kedua yaitu dengan variabel independen $(\mathrm{X})$ adalah sales promotion, dan variabel dependen $(\mathrm{Y})$ adalah perilaku konsumen. Maka analisis yang digunakan untuk melihat pengaruh variabel $\mathrm{X}$ dan variabel Y adalah dengan rumus sebagai berikut :

$$
\mathbf{Y}=\mathbf{a}+\mathbf{b X}
$$

Dimana :

$\mathrm{Y}=$ Sales Promotion $\mathrm{a}=$ Intercept / Konstanta Y b = Koefisien arah regresi

$\mathrm{X}=$ Perilaku Konsumen

\section{Hasil Penelitian}

Berdasarkan hasil uji t, yaitu untuk menguji apakah variabel bebas memiliki pengaruh signifikan terhadap nilai variabel terikat.

Tabel 1.

Analisis Regresi Linier Sederhana

Coefficients

\begin{tabular}{|c|c|c|c|c|c|}
\hline \multirow[t]{2}{*}{ Model } & \multicolumn{2}{|c|}{$\begin{array}{l}\text { Unstandardized } \\
\text { Coefficients }\end{array}$} & $\begin{array}{l}\text { Standardizzd } \\
\text { Coefficients }\end{array}$ & \multirow[t]{2}{*}{ t } & \multirow[t]{2}{*}{ Sig. } \\
\hline & B & Std Erru & Beta & & \\
\hline (Constant) & 18.883 & 3.861 & & 4.891 & .000 \\
\hline Sales Promotion & .481 & .143 & .420 & 3.369 & .001 \\
\hline
\end{tabular}

Sumber : Data Diolah.

Nilai thitung diperoleh dengan bantuan program SPSS versi 18.00 seperti yang terlihat pada Tabel 1 kolom kelima terlihat thitung variabel sales promotion $(\mathrm{X})$ adalah 3,369. Nilai tabel pada $\alpha=5 \%$ untuk uji satu arah, dengan derajat kebebasan $(\mathrm{df})=(\mathrm{n}-\mathrm{k})$ yaitu $(55-2)=53$ yaitu 1,298. Maka variabel sales promotiondinyatakan berpengaruh signifikan terhadap prilaku konsumen dengan kriteria $t_{\text {hitung }}>t_{\text {tabel }}$ atau 3,369 >1,298. Maka Ha diterima dan Ho ditolak.Berdasarkan kriteria uji hipotesis, maka disimpulkan : "Variabel sales promotionberpengaruh signifikan terhadap perilaku konsumen pada CV. Indah Sakti Rantauprapat. 


\section{Kesimpulan}

Berdasarkan hasil penelitian menunjukkan bahwa sales promotion terhadap perilaku konsumen sangat signifikan.

\section{Daftar Pustaka}

Alma, Buchari. 2007. Manajemen Pemasaran dan Pemasaran Jasa , Edisi Revisi, Alfabeta: Bandung.

Bungin, Burhan. 2001. Metodologi Penelitian Kualitatif Dan Kuantitatif. Yogyakarta:Gajah Mada Press.

Hasan, Ali, 2013. Marketing dan Kasus-Kasus Pilihan. Yogyakarta. CAPS.

Kotler, Philip and Gary Armstrong. 2008. Prinsip-prinsip Pemasaran. Edisi. 12. Jilid 1. Jakarta: Erlangga.

Kotler, Philip, dan Kevin Lane Keller. 2009. Manajemen Pemasaran. Jilid 1 Edisi Terjemahan 12. Jakarta: Indeks.

Sumarwan, Ujang, Herien Puspitawati, Agustinus Hariadi, Mochammad Mukti Ali, Muhammad Gazali, Sri Hartono, Tara Farina. 2013. Riset Pemasaran dan Konsumen. Bogor: IPB Press

Sunyoto, Danang. 2013. Perilaku Konsumen: Panduan Riset Sederhana untuk Mengenali Konsumen. Jakarta: PT. Buku Seru.

Tjiptono, Fandy. 2008. Strategi Pemasaran, Edisi 3, ANDI: Yogyakarta 